\title{
DETERMINANTS OF FINANCIAL WELLNESS OF RURAL HOUSEHOLDS IN THE HILL DISTRICTS OF UTTARAKHAND: AN EMPIRICAL APPROACH
}

\author{
Ajay Purohit \\ Research Scholar \\ School of Management \\ IMS UNISON University, Dehradun, Uttarakhand, India \\ E-mail: ajaypurohit_in@hotmail.com \\ (Dhttps://orcid.org/0000-0001-9369-6083 \\ Dr. Gaurav Chopra \\ Assistant Professor \\ School of Management \\ IMS UNISON University, Dehradun, Uttarakhand, India \\ E-mail: gauravschopra19@gmail.com \\ (D)https://orcid.org/0000-0002-1238-6831

\section{Dr. Parshuram G Dangwal} \\ Associate Professor \\ School of Management \\ IMS UNISON University, Dehradun, Uttarakhand, India \\ E-mail:pgdangwal@gmail.com \\ (D)https://orcid.org/0000-0002-9504-1344
}

Received: October 27, 2021 Accepted: December 30, $2021 \quad$ Online Published: January 24, 2022

DOI: $10.46281 / \mathrm{ijfb.v9i1.1566}$

URL: https://doi.org/10.46281/ijfb.v9i1.1566

\begin{abstract}
The study examines significant contributors to financial wellness for rural households in the hill districts of Uttarakhand. The study takes a sample of 666 respondents through multi-stage stratified random sampling from Self-Help Groups (SHGs) and Cooperatives members, and all are small and marginal farmers. A field survey was conducted using a structured questionnaire. Except for financial knowledge and numeracy, all other constructs, such as cash management, savings behavior, risk-credit management, financial attitudes, and financial wellness, were measured on a seven-point Likert scale ranging from strongly disagree to strongly agree. Exploratory Factor Analysis (EFA), Confirmatory Factor Analysis (CFA), and Structural Equation Modelling (SEM) were conducted on 628 valid samples using SPSS 23 and AMOS 23. The results from the analysis revealed that cash management, savings behavior, and financial attitudes significantly contribute to financial wellness. The study found that households have the reasonable financial knowledge and financial numeracy skills. The study also found that savings behavior has a mediating effect on the relationship between cash management and financial wellness. The study is useful for rural development stakeholders and policymakers to strategically focus on financial inclusion programs.
\end{abstract}


Keywords: Financial Wellness, Financial Behavior, Financial Literacy, Financial Inclusion, Rural, SelfHelp Groups.

JEL Classification Codes: D14, G51, G52, G53, I30.

\section{INTRODUCTION}

Financial wellness or financial well-being or economic well-being or financial satisfaction denotes financial situation or financial health. It is a multidimensional aspect and objective as well as subjective concept in nature (Vieira et al., 2021), (Iramani \& Lutfi, 2021), (Tanoto \& Evelyn, 2019), (Brüggen et al., 2017). Financial inclusion, financial behavior, financial attitude, financial literacy are other terminologies associated with financial wellness in multiple studies. Financially well households easily meet the current needs and deal with sudden needs of an individual or a household (Vieira et al., 2021), (Masenya \& Dickason-Koekemoer, 2020), (Michael Collins \& Urban, 2020), (Simonova, 2019), (CFPB, 2017), (CFPB, 2015). Holistically, financial wellness is directly and indirectly connected to economic upliftment and an essential growth driver to achieve sustainable development goals (Wadhwa, 2020), (Rickard \& Johnsson, 2018), (Klapper et al., 2016), (UNCTAD, 2015). Factors like demographic aspects (gender, education, etc.), income, savings, opportunities, accessibility, the package of practices, urban, rural, and others impact financial wellness.

In the rural hilly areas, due to distinct geographical scenarios, situations are different from the plains. The plain area has more opportunities than the hills; therefore, high-income inequalities are reflected in plain and rural areas (Suryanarayana \& Mamgain, 2017), (Mamgain \& Reddy, 2015). Around $86 \%$ of geographical areas are under hilly terrain in the state, and $71.05 \%$ are covered under forest. $70.37 \%$ of the state population lives in rural areas and is primarily engaged in agriculture and allied activities (DES, 2020). Horticulture and agriculture are identified as growth drivers of the state economy in the state vision 2030 (GoUK, 2018). However, income from agriculture and allied activities is not significantly high at the individual household's level because of less volume, high marketing cost, and other distinguishing factors of hills (Kandpal \& Kavidayal, 2020). For economic growth and sustainable livelihood, households have organized in the Self-Help Groups (SHGs) at the village level and into Cooperatives at the cluster level. The present study has been conducted with SHGs members from the hill districts of Uttarakhand. All members are small and marginal farmers (Note 1).

State Rural Livelihood Mission (SRLM) and Integrated Livelihood Support Project (ILSP) are two main programs being executed in Uttarakhand. SRLM promotes women's SHGs exclusively (RBI, 2019), whereas ILSP has more than $85 \%$ of women members in their groups (CPCU, 2020). SHGs followed the core concepts of 'Panchasutras' (Note 2) for cohesiveness, sustainability, and mitigating financial constraints in tough times. Under financial inclusion, they provide training and facilitate financial instruments e.g., accounts, investment, insurance e.g., PM Jeevan Jyoti Bima Yojana, PM Suraksha Bima Yojana, credit schemes e.g., Kisan Credit Card, Mudra loan, etc. (CPCU, 2020).

The main objective of this study is to identify the significant factors behind financial wellness in the context of rural households in the hill districts of Uttarakhand. All households are members of SHGs, and Cooperatives and also come small and marginal farmers. To identify the construct, exploratory factor analysis (EFA), and confirmatory factor analysis (CFA) have been used. Further, structure equation model (SEM), and path analysis have been used to find the mediating role of savings behavior, and results are presented.

\section{Financial Wellness}

\section{LITERATURE REVIEW}

Based on previous studies (Botha \& New, 2021), (OECD, 2020), (Mahdzan et al., 2020), (Heath et al., 2018), (Predergast et al., 2018), (CFPB, 2017), (CFPB, 2015) financial wellness refers to household's (i) financial health (like income, savings) to fulfill daily and emergency requirements in current as well as future, (ii) financial security and financial freedom in the life course, and (iii) ability of effective financial management. (Masenya \& Dickason-Koekemoer, 2020), (Heo et al., 2020) study revealed that financial wellness positively correlates with satisfaction with life, whereas life satisfaction refers to an 
individual's satisfaction towards happiness and subjective well-being. In a nutshell, financial wellness is a reflection of fulfilling the household's financial necessities, enhancement of economic status, better living conditions, cost-effective package of financial practices and perception of satisfaction.

According to (PwC, 2020), ( $\mathrm{PwC}, 2014)$ employee financial wellness survey, financial wellness is significantly correlated with financial literacy for decision-making and financial behavior towards savings, investments, credit, and others. Multiple reports and research (Botha \& New, 2021), (OECD, 2020), (Heath et al., 2018), (Gautam \& Andersen, 2016) (Brüggen et al., 2017), (CFPB, 2017), (Coşkuner, 2016), (CFPB, 2015) examined financial wellness with multiple corresponding constructs financial behavior, financial attitude, financial knowledge, financial solvency, income, education, and individual characteristics.

\section{Financial Behaviors}

Financial behavior is a kind of behavior that influences taking a correct financial decision about cash, credit, risk, and savings (IGI-Global, 2021b), (Iramani \& Lutfi, 2021), (Zulaihati \& Widyastuti, 2020). Financial behavior is a direct and indirect influencer of financial wellness and is associated with financial literacy, income, gender, marital status, homeownership, education, to name a few. Innovative practices of cash and savings reduce the consequences of any emergency or mishap. The financial behavior of rural households is significantly correlated with financial literacy and savings (Murari, 2019). Therefore, financial behaviors can be measured through one's practice and perception, including cash management in day-to-day life, savings for the future, risk, and credit management to reduce the debt and mitigate the financial losses.

\section{Cash Management}

Cash management is maintaining cash in hands and effectively utilizing income so that the person can be inclined towards achieving future goals while fulfilling the present needs and realizing future needs. Every household prepares a tentative plan or budget for recurring expenses and other investment purposes (Widyastuti et al., 2020), (Murari, 2019). Cash management is a practice of allocation and distribution of income for day to day expenses, savings for futuristic goals, and assets creation which has a significant impact on financial wellness (Adiputra, 2021), (Fazli Sabri et al., 2020), (Wahab \& Yaacob, 2018), (Ameliawati \& Setiyani, 2018). Thus, from the pioneering studies, the following hypothesis has been formulated:

\section{$H_{1}$ : Cash management has a significant impact on financial wellness.}

\section{Savings Behaviour}

It is natural to set aside a portion of one's earnings for future aspirations and emergencies. Sufficient savings reduces unexpected social and financial shocks (Despard et al., 2020), (Gaisina \& Kaidarova, 2017). Banks and Post Offices are common financial institutions for savings. SHG members also save regularly in their respective groups. Generally, it is small in terms of amount, but regular as decided in the group like weekly or monthly. Group savings have been utilized for specific and prominent needs (DAY-NRLM, 2017). Households also save their cash at home and deposit savings with friends, family members, moneylenders (Coleman \& Wynne-williams, 2006). Several researchers (Gaisina \& Kaidarova, 2017), (Nguyen et al., 2017), (Lee \& Hanna, 2015) examined saving behavior and revealed that it has a significant influence on financial wellness. Therefore, based on literature support, we found savings are self-actualization of financial wellness. Thus, from the literature, the following hypothesis has been formulated:

\section{$\mathrm{H}_{2}$ : Savings behavior has a significant impact on financial wellness.}

\section{Risk and Credit Management}

Risk management is conceptualized to reduce the impact of any jolt from any risk in life, health, assets, crops, livestock, and others. (Robb \& Woodyard, 2011) identified risk and credit management are best 
financial practices. Unexpected financial risk is reduced through insurances and increased savings (Murugesan \& Manohar, 2020), (Woodyard, 2013), and (OECD, 2013). Insurance is a one-time or regular investment; however, it requires income, accessibility, and financial literacy. Low-income households face different risks and shocks e.g., income volatility, livelihood risks, health, weather (Vishwanath et al., 2020). They can't afford insurance (Rampini \& Viswanathan, 2016). However, the government is promoting credit cum insurance schemes, which are affordable to low-income households. As per need, rural households take loans from SHG at a nominal interest rate, which is extremely low compared to other sources. Still, households avoid taking loans except in emergencies. Overall, high credit, unforeseen risk affect savings, increase stress, and impact financial wellness. Based on the literature, the following hypothesis has been formulated:

\section{H3: Risk-credit management has a significant impact on financial wellness.}

\section{Financial Literacy}

"National Strategy for Financial Education 2020-2025" (RBI, 2021) indicates that "the achievement of Financial Literacy empowers the users to make sound financial decisions which result in financial wellbeing of the individual." According to (Chong et al., 2021), (Stella et al., 2020), (N. Ismail \& Zaki, 2019), (OECD, 2018), (Topa et al., 2018), (Skagerlund et al., 2018), (Jayanthi \& Rau, 2017), and (Bilal \& Zulfiqar, 2016) financial literacy is one's perception and knowledge about financial resources, effective utilization of financial instruments and financial decision-making skills towards economic sustainability and improvement during one's life course. It is a set of skills influenced by knowledge, a package of practices, awareness, and practices in the community, accessibility of resources, education, income, and self-actualization. Definitions indicate that the two core elements of financial literacy are financial knowledge and financial attitude, and they complement each other.

\section{Financial Knowledge}

Previous research revealed a strong association among financial knowledge, financial behavior, and financial wellness (Adiputra, 2021), (Stella et al., 2020), (Choudhary \& Kamboj, 2017), (Gaisina \& Kaidarova, 2017), (Kamakia et al., 2017), and (Potrich et al., 2016). Financial knowledge helps to make profitable financial decisions, effective use of financial products and services, improve financial behaviors towards sustainable economic growth and happiness (Atmaningrum et al., 2021), (OECD, 2020), (Nguyen et al., 2017), (Aren \& Aydemir, 2014). Training, capacity buildings, and exposures mainly in financial products and services increase financial knowledge. It is necessary for all to take a correct financial decision in terms of financial products and services that increase financial wellness (N. Ismail \& Zaki, 2019), (Kamakia et al., 2017), (Phani Kumar, 2016), and (Muleke \& Muriithi, 2013). (Zhan et al., 2006) assessed pre-post financial training of low-income population and suggested that financial literacy training significantly increases economic management practices that lead to financial wellness.

\section{Financial Attitude}

A financial attitude is a perception or tendency towards financial products and services (IGI-Global, 2021a). Financial attitude influences financial management, which impacts future wellness (RBI, 2021), (OECD/INFE, 2013). It means that a positive financial attitude towards budgeting, savings, and money has positive financial behavior. It varies from person to person, depending upon financial knowledge as well as demographic variables. Several researchers (Adiputra, 2021), (Abdullah et al., 2019), (Ameliawati \& Setiyani, 2018), (Forouzani \& Mohammadzadeh, 2018), (Garber \& Koyama, 2017), explained the significant relationship between financial attitude and financial wellness. (Potrich et al., 2016) explained in their model that financial knowledge and financial attitude have positive impacts on financial wellness. Based on the literature review, the following hypothesis has been formulated:

\section{$H_{4}$ : Financial attitude has a significant impact on financial wellness.}




\section{Demographic Factors}

Demographic cohorts like age, gender, education, income, family size, assets, and socio-economic status always influence financial wellness and its other contributors. (Collins \& Urban, 2020) the study explained that age and income have a significant impact on financial wellness and relative variables. (Woodyard \& Robb, 2012) examined gender and age-wise financial satisfaction and financial behavior. (Vosloo et al., 2014) study indicates that less income and less or lack of financial benefits, higher debt levels create financial stress, which impacts negatively on a person performance at work. (N. Ismail \& Zaki, 2019) explained that factors like employment opportunities, income instability, family size, financial self-efficacy, and financial help-seeking behavior impact the financial wellness of the lowmedium class. (Kesavan, 2020) recommended that the regular and multiple sources of income like agriculture, livestock, and community works support catalyze financial inclusion. Based on the literature review, demographic cohorts like gender, age, education, land size, income, and savings were included in the study.

\section{Savings Behavior as a Mediator}

The primary source of income is agriculture and allied activities in the rural areas. Revenue from these sources varies due to a number of factors like production, market, and weather. Hence, the income is irregular, and savings is one of the crucial sources in every situation for all households. (Lulaj et al., 2021), (Jin et al., 2021), (S. Ismail et al., 2018), (Shin \& Kim, 2018), (Magendans et al., 2017) research indicated that savings play an important role in emergencies and significant contribution to financial wellness. (Gjertson, 2016) the study found that savings are a kind of insurance of low-income households which protects against hardship. (Iramani \& Lutfi, 2021) explained that a household's savings and income are positively correlated with their financial wellness. (Wieliczko et al., 2020) highlighted in their study that savings as a growth driver of sustainable development of farmers and a core pillar of financial security. (Martin \& Hill, 2015) establish financial situation- poverty-well-being relationship, and found savings is a core factor of well-being. Briefly, we can conclude that effective cash management and positive savings behavior increase savings, and subsequently, financial wellness. As such, we predict the following mediation hypotheses:

\section{$H_{5}$ : Savings behavior mediates the relationship between cash management and financial wellness.}

\section{RESEARCH METHODOLOGY}

The primary objective was to identify the groups of factors that significantly explain financial wellness, especially in the context of rural households in hill districts of Uttarakhand. All are members of SHGs and Cooperatives and also come under small and marginal farmers. The study was conducted in the 21 hill blocks from hill districts of Uttarakhand through multi-stage stratified random sampling. Total 666 samples were collected from upper hills, middle hills, and foothills. The Survey method was used to collect the data with the help of a structured questionnaire. A structured questionnaire was used to gather data from the respondents. The questionnaire was developed through literature review and translated into the native language, "Hindi". To improve the questionnaire's accuracy, a pilot test on 70 respondents was conducted with rural households, and related modifications have been implemented. Then, a sample of 50 respondents, distinct from those included in the pilot test, were asked to pre-test the questionnaire. Other than the demographic cohort, the questionnaire consisted of 5 major sections, i.e., cash management, savings behavior, risk-credit management, financial knowledge, and financial attitude. All sections except financial knowledge were measured on a seven-point Likert scale ranging from strongly disagree to strongly agree. After data cleaning (missing values, outliers), 628 responses were analyzed using SPSS 23 and AMOS 23. 
Table 1. Demographic features

\begin{tabular}{|c|c|c|c|}
\hline Measure & Items & Frequency & $\%$ \\
\hline \multirow[t]{3}{*}{ Gender } & Male & 79 & 12.6 \\
\hline & Female & 549 & 87.4 \\
\hline & Total & 628 & 100.0 \\
\hline \multirow{5}{*}{$\begin{array}{c}\text { Education } \\
\text { Qualification }\end{array}$} & Less than Eight Class & 182 & 29.0 \\
\hline & Intermediate & 300 & 47.8 \\
\hline & Graduate & 92 & 14.6 \\
\hline & Postgraduate & 54 & 8.6 \\
\hline & Total & 628 & 100 \\
\hline \multirow[t]{6}{*}{ Age } & 20 to 30 & 87 & 13.9 \\
\hline & 30 to 40 & 273 & 43.5 \\
\hline & 40 to 50 & 171 & 27.2 \\
\hline & 50 to 60 & 80 & 12.7 \\
\hline & More than 60 & 17 & 2.7 \\
\hline & Total & 628 & 100 \\
\hline \multirow{6}{*}{$\begin{array}{c}\text { Average Monthly } \\
\text { Income (including all } \\
\text { sources) }\end{array}$} & Less than INR 6000 & 247 & 39.0 \\
\hline & INR 6000 to INR 9000 & 189 & 30.1 \\
\hline & INR 9000 to INR 12000 & 89 & 14.2 \\
\hline & INR 12000 to INR 15000 & 49 & 7.8 \\
\hline & More than INR 15000 & 54 & 8.6 \\
\hline & Total & 628 & 100 \\
\hline \multirow{6}{*}{$\begin{array}{c}\text { Average Monthly } \\
\text { Savings (including all } \\
\text { sources) }\end{array}$} & Less than INR 600 & 257 & 40.9 \\
\hline & INR 600 to INR 900 & 150 & 23.9 \\
\hline & INR 900 to INR 1200 & 80 & 12.7 \\
\hline & INR 1200 to INR 1500 & 54 & 8.6 \\
\hline & More than INR 1500 & 87 & 13.9 \\
\hline & Total & 628 & 100 \\
\hline \multirow[t]{6}{*}{ Land Size (in hectare) } & Less than 0.04 & 100 & 15.9 \\
\hline & Between 0.04 to 0.08 & 146 & 23.2 \\
\hline & Between 0.08 to 0.120 & 155 & 24.7 \\
\hline & Between 0.120 to 0.160 & 118 & 18.8 \\
\hline & More than 0.160 & 109 & 17.4 \\
\hline & Total & 628 & 100 \\
\hline \multirow{5}{*}{$\begin{array}{l}\text { Who is responsible } \\
\text { for making major } \\
\text { financial decisions } \\
\text { (like investment, } \\
\text { purchase, etc.) in your } \\
\text { family? }\end{array}$} & Myself & 127 & 20.2 \\
\hline & Wife / husband & 144 & 22.9 \\
\hline & Both, after discussion & 278 & 44.3 \\
\hline & Elder family Members & 79 & 12.6 \\
\hline & Total & 628 & 100 \\
\hline
\end{tabular}

\section{DATA ANALYSIS AND RESULTS}

Demographic data Table-1 indicates $87.4 \%$ of respondents were female respondents. $76.8 \%$ have education qualification up to intermediate. $43.5 \%$ of the respondents were between the ages of 30 and 40. About $69.1 \%$ of the respondents had an average monthly income of less than INR 9000, and $64.8 \%$ had an average monthly saving of less than INR 900. Interestingly, the financial decision in $44.3 \%$ family is taken after discussion and mutual consent of husband and wife. 
Table 2. Financial Knowledge

\begin{tabular}{|c|c|c|c|}
\hline & Items & Yes $(\%)$ & No $(\%)$ \\
\hline \multirow{6}{*}{$\begin{array}{l}\text { Financial } \\
\text { Knowledge }\end{array}$} & FL1K1 & 79.6 & 20.4 \\
\hline & FL2K2 & 86.6 & 13.4 \\
\hline & FL2K3 & 93.2 & 6.8 \\
\hline & FL2K4 & 87.9 & 12.1 \\
\hline & FL2K5 & 78.3 & 21.7 \\
\hline & Items & Correct Answer (\%) & Incorrect Answer (\%) \\
\hline \multirow{4}{*}{$\begin{array}{l}\text { Numerical } \\
\text { Skills }\end{array}$} & FL2NS1 & 91.9 & 8.1 \\
\hline & FL2NS2 & 73.7 & 26.3 \\
\hline & FL2NS3 & 87.9 & 12.1 \\
\hline & FL2NS4 & 42.5 & 57.5 \\
\hline
\end{tabular}

Table- 2 indicates that $79.6 \%$ of respondents were aware that if they save their savings in Bank / Post office, they will get more benefits than other informal arrangements. Interestingly, $86.6 \%$ of respondents know about the interest rate of fixed deposits. 93.2\% of respondents know about PM Jan Dhan Account, and $87.9 \%$ of respondents know the details of PM Kisan Samman Nidhi Scheme. The results indicate that respondents have good financial knowledge. It reflects the outcome of training, capacity-building programs, and other activities implemented under financial inclusion by different institutions (RBI, 2021), (Wadhwa, 2020).

91.9\% of respondents correctly calculated day-to-day financial calculations. $73.7 \%$ of respondents correctly calculated group savings. The results indicate that the members of informal savings groups actively participate in the group meetings. $87.9 \%$ of respondents can calculate dividends, which indicates that all shareholders know how dividends are calculated. However, only $42.5 \%$ of respondents correctly calculated simple interest, and $52.4 \%$ gave mathematically wrong answers. Overall, the study shows that the rural households in the hill districts have financial knowledge.

\section{Reliability Test}

The quality and consistency of the survey were further assessed using Cronbach's alpha (.820) which is greater than .7, hence acceptable (George \& Mallery, 2016).

Table 3. Reliability statistics

\begin{tabular}{|c|c|}
\hline Cronbach's Alpha & N of Items \\
\hline 0.820 & 19 \\
\hline
\end{tabular}

\section{Exploratory Factor Analysis}

EFA has been conducted for dimension reduction through varimax, principal component analysis, and rotated component matrix. Total 19 items with a sample of 628 were used for analysis. Five factors were extracted through eigenvalue $(>1)$ and scree test (Figure 1) with the significant $(>0.40)$ loadings (Hair, Sarstedt, et al., 2017). Table-4 states that all assumptions of EFA are met. All the items have been loaded appropriately in the factor analysis (Table-5) and have passed the reliability test. Three items have been grouped into financial wellness, four items in cash management, three items in attitude towards savings, five items in credit-risk management, and four items in financial attitude. 
Table 4. Assumptions for EFA

\begin{tabular}{|l|l|l|}
\hline & Conditions & Reference (Chopra et al., 2019) \\
\hline Sample size is 628 & $\mathrm{n}>200$ & (Kyriazos, 2018) \\
\hline Barlett's test of sphericity is significant & $\mathrm{p}<0.001$ & (Watkins, 2018) \\
\hline $\begin{array}{l}\text { KMO value is 0.879 measure of } \\
\text { sampling adequacy }\end{array}$ & $>0.70$ & (Watkins, 2018) \\
\hline Satisfactory communalities values & $>0.50$ & (Field, 2018) \\
\hline Total variance explained is 74.685\% & $>50 \%$ & (Podsakoff \& Organ, 1986) \\
\hline $\begin{array}{l}\text { The variance for the first factor is } \\
17.461 \%\end{array}$ & $<50 \%$ & (Podsakoff \& Organ, 1986) \\
\hline
\end{tabular}

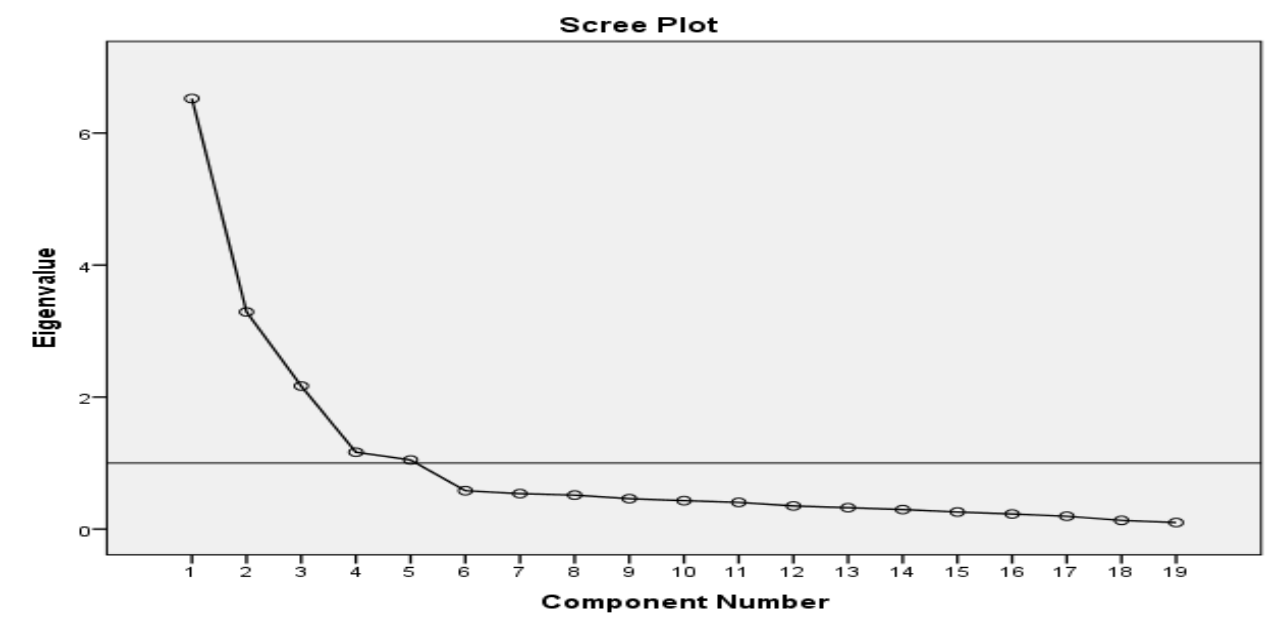

Figure 1. Scree Plot

Table 5. Rotated Component Matrix

\begin{tabular}{|c|c|c|c|c|c|c|}
\hline & & & mpon & & & \\
\hline & 1 & 2 & 3 & 4 & 5 & Cronbach's Alpha \\
\hline FW1 & & & .879 & & & 0.935 \\
\hline FW2 & & & .875 & & & \\
\hline FW3 & & & .788 & & & \\
\hline FB1CM1 & & .726 & & & & 0.871 \\
\hline FB1CM2 & & .686 & & & & \\
\hline FB1CM3 & & .858 & & & & \\
\hline FB1CM4 & & .843 & & & & \\
\hline FB2S1 & & & & & .755 & 0.831 \\
\hline FB2S2 & & & & & .733 & \\
\hline FB2S3 & & & & & .805 & \\
\hline FB3RCM1 & .776 & & & & & 0.863 \\
\hline FB3RCM2 & .698 & & & & & \\
\hline FB3RCM3 & .892 & & & & & \\
\hline FB3RCM4 & .901 & & & & & \\
\hline FB3RCM5 & .738 & & & & & \\
\hline FL3A1 & & & & .809 & & 0.864 \\
\hline FL3A2 & & & & .838 & & \\
\hline FL3A3 & & & & .870 & & \\
\hline FL3A4 & & & & .788 & & \\
\hline
\end{tabular}




\begin{tabular}{|l|c|c|c|c|c|c|}
\hline $\begin{array}{l}\text { Rotation Sums of } \\
\text { Squared Loadings }\end{array}$ & 17.461 & 33.063 & 48.633 & 63.105 & 74.685 & \\
\hline
\end{tabular}

\section{Confirmatory Factor Analysis}

According to (Xia \& Yang, 2019), (Hair, Hult, et al., 2017), and (Kline, 2016) studies, the model must have acceptable convergent and reliability validity as well as model-fit indices through first-order CFA.

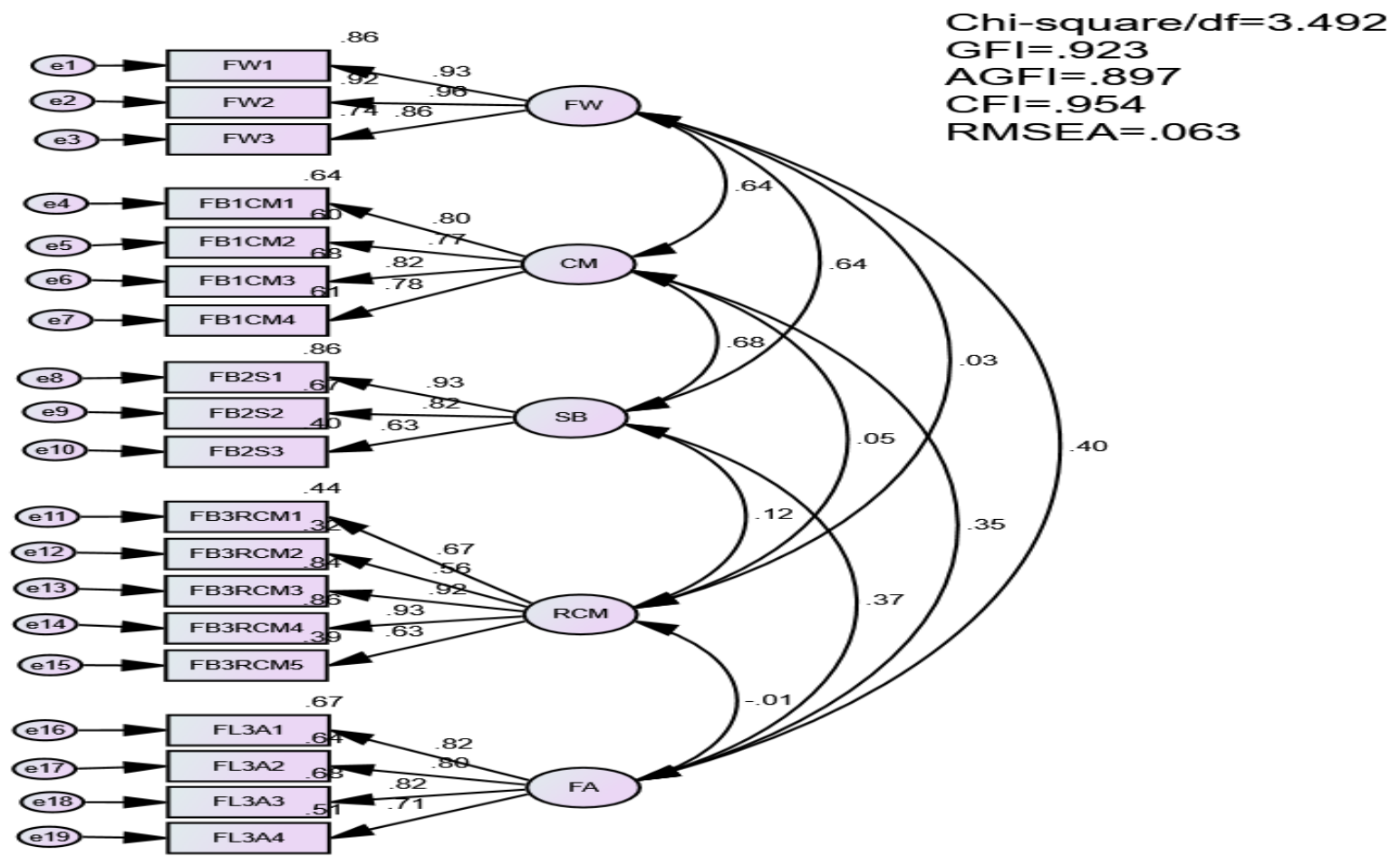

Financial wellness: FW, Cash management: CM,

SB: Savings behaviour, RCM: Risk-credit management, FA: Financial attitude

Figure 2. Confirmatory Factor Analysis

\section{The Goodness of Fit Indices}

The recommended fit indices' values and their threshold limits are presented in Table-6, which shows that all values meet the threshold criteria. However, $p$-value of $\chi 2<0.05$, which may be because of the large sample size (>200) (Kline, 2016), (Bentler \& Bonett, 1980). However, absolute fit indices, relative fit indices, and non-centrality-based indices values make the model acceptable.

Table 6. Goodness of fit indices

\begin{tabular}{|l|c|c|c|c|}
\hline \multicolumn{1}{|c|}{ Fit index } & Limit & $\begin{array}{c}\text { Values in the } \\
\text { present study }\end{array}$ & $\begin{array}{c}\text { References } \\
\text { (Hooper et al., 2008), } \\
\text { (Chopra \& Madan, 2021), } \\
\text { (Gaskin, 2021) }\end{array}$ & Acceptability \\
\hline \multicolumn{2}{|l|}{ Absolute fit indices } & \multicolumn{3}{|l|}{} \\
\hline$\chi 2$ & & 142 & & No \\
\hline df & $>0.05$ & 0.000 & & Yes \\
\hline $\mathrm{p}$ value & $1.00-5.00$ & 3.492 & (Kline, 2016) & \\
\hline$\chi 2 / \mathrm{df}$ &
\end{tabular}




\begin{tabular}{|l|c|l|l|c|}
\hline SRMR & $<0.08$ & 0.063 & $($ Hu \& Bentler, 1999) & Yes \\
\hline GFI & $>0.90$ & 0.923 & $($ Hu \& Bentler, 1999) & Yes \\
\hline \multicolumn{7}{|l|}{ AGFI } & $>0.80$ & 0.897 & $($ Hu \& Bentler, 1999) & Yes \\
\hline \multicolumn{7}{|l|}{ Relative fit indices } \\
\hline NFI & $>0.80$ & 0.937 & (Bentler \& Bonett, 1980) & Yes \\
\hline PNFI & $>0.50$ & 0.778 & (Bentler \& Bonett, 1980) & Yes \\
\hline IFI & $>0.90$ & 0.954 & (Bollen, 1990) & Yes \\
\hline TLI & $>0.90$ & 0.945 & (Tucker \& Lewis, 1973) & Yes \\
\hline Non-centrality-based indices & \multicolumn{5}{|l|}{} \\
\hline CFI & $>0.90$ & 0.954 & (Hu \& Bentler, 1999) & Yes \\
\hline PGFI & $>0.50$ & 0.690 & (Mulaik et al., 1989) & Yes \\
\hline RMSEA & $<0.08$ & 0.063 & (Xia \& Yang, 2019) & Yes \\
\hline
\end{tabular}

\section{Convergent Validity}

According to (Hair, Hult, et al., 2017), the composite reliability of all the constructs must be more than 0.7 , for attaining the construct reliability. The average variance extracted (AVE) required is above 0.500, and MSV must be less than AVE for convergent validity. All recommended conditions are passed for the proposed model (Table 7), so we can conclude that the proposed model has a convergent validity.

Table 7. Convergent validity parameters

\begin{tabular}{|c|c|c|c|c|c|}
\hline Construct & Items & $\begin{array}{l}\text { Factor } \\
\text { Loading } \\
\text { (above 0.5) }\end{array}$ & $\begin{array}{l}\text { Composite } \\
\text { reliability } \\
\text { (above 0.7) }\end{array}$ & $\begin{array}{l}\text { AVE } \\
\text { (above } \\
0.5)\end{array}$ & $\begin{array}{l}\text { MSV (less } \\
\text { than AVE) }\end{array}$ \\
\hline \multirow{3}{*}{$\begin{array}{l}\text { Financial Wellness } \\
(\mathrm{FW})\end{array}$} & FW1 & 0.928 & 0.940 & 0.840 & 0.411 \\
\hline & FW2 & 0.959 & & & \\
\hline & FW3 & 0.860 & & & \\
\hline \multirow{4}{*}{$\begin{array}{l}\text { Cash Management } \\
\text { (CM) }\end{array}$} & FB1CM1 & 0.801 & 0.872 & 0.631 & 0.463 \\
\hline & FB1CM2 & 0.773 & & & \\
\hline & FB1CM3 & 0.823 & & & \\
\hline & FB1CM4 & 0.778 & & & \\
\hline \multirow[t]{3}{*}{ Savings Behavior (SB) } & FB2S1 & 0.927 & 0.840 & 0.642 & 0.463 \\
\hline & FB2S2 & 0.818 & & & \\
\hline & FB2S3 & 0.631 & & & \\
\hline \multirow{5}{*}{$\begin{array}{l}\text { Risk-credit } \\
\text { Management (RCM) }\end{array}$} & FB3RCM1 & 0.667 & 0.865 & 0.572 & 0.015 \\
\hline & FB3RCM2 & 0.564 & & & \\
\hline & FB3RCM3 & 0.917 & & & \\
\hline & FB3RCM4 & 0.929 & & & \\
\hline & FB3RCM5 & 0.626 & & & \\
\hline \multirow{4}{*}{$\begin{array}{l}\text { Financial Attitude } \\
\text { (FA) }\end{array}$} & FL3A1 & 0.819 & 0.869 & 0.624 & 0.162 \\
\hline & FL3A2 & 0.797 & & & \\
\hline & FL3A3 & 0.824 & & & \\
\hline & FL3A4 & 0.714 & & & \\
\hline
\end{tabular}

\section{Discriminant Validity}

Discriminant validity expresses the uniqueness of each construct from other constructs by empirical standards (Hair, Hult, et al., 2017). To examine discriminant validity, we analyzed AVE > MSV, and the square root of AVE is greater than inter-construct correlations (Table-8). Thus, we can conclude that all the constructs in the proposed model have discriminant validity. 
Table 8. Discriminant validity

\begin{tabular}{|l|c|c|c|c|c|}
\hline & $\begin{array}{c}\text { Financial } \\
\text { Wellness }\end{array}$ & $\begin{array}{c}\text { Cash } \\
\text { Management }\end{array}$ & $\begin{array}{c}\text { Risk-credit } \\
\text { Management }\end{array}$ & $\begin{array}{c}\text { Savings } \\
\text { Behavior }\end{array}$ & $\begin{array}{c}\text { Financial } \\
\text { Attitude }\end{array}$ \\
\hline Financial Wellness & $\mathbf{0 . 9 1 7}$ & & & & \\
\hline Cash Management & 0.637 & $\mathbf{0 . 7 9 4}$ & & & \\
\hline Risk-credit Management & 0.029 & 0.048 & $\mathbf{0 . 7 5 6}$ & & \\
\hline Savings Behavior & 0.641 & 0.680 & 0.122 & $\mathbf{0 . 8 0 2}$ & \\
\hline Financial Attitude & 0.402 & 0.349 & -0.007 & 0.368 & $\mathbf{0 . 7 9 0}$ \\
\hline
\end{tabular}

\section{Structured Model}

After verify model fit, and validity, path analysis has been run on AMOS 23. Figure 3 shows the results of a structure model drawn on AMOS graphics. The goodness of fit indices was Chi-square/df $=3.593$, $\mathrm{SRMR}=0.067, \mathrm{GFI}=0.920, \mathrm{AGFI}=0.894, \mathrm{NFI}=0.934, \mathrm{PNFI}=0.787, \mathrm{IFI}=0.952, \mathrm{TLI}=0.942, \mathrm{CFI}$ $=0.951$, PGFI $=0.697$, and RMSEA $=0.64$. Table-9 presents standardized regression weights of all the relationships present in the model. Apart from RCM, all values are significant ( $\mathrm{p}$-value $<0.05$ ). Therefore, hypothesis $\mathrm{H} 1, \mathrm{H} 2$ and $\mathrm{H} 4$ are accepted and $\mathrm{H} 3$ rejected. Therefore, we can conclude that cash management, savings behavior, and financial attitude have significant impact on financial wellness.

Table 9. Standardized Regression Weights: hypothesis testing

\begin{tabular}{|l|c|c|c|c|c|}
\hline \multicolumn{1}{|c|}{ Hypothesis } & Estimate & S.E. & C.R. & P & Acceptance / rejection \\
\hline H1 - "Cash management has a significant impact on financial wellness. & \\
\hline FW <--- CM & 0.346 & 0.104 & 6.441 & $* * *$ & Accepted \\
\hline H2 - "Savings behavior has a significant impact on financial wellness.” & \\
\hline FW <--- SB & 0.355 & 0.037 & 16.418 & $* * *$ & Accepted \\
\hline H3 - "Risk-credit management has a significant impact on financial wellness. ” \\
\hline FW <--- RCM & -0.290 & 0.110 & -0.908 & $\begin{array}{c}0.36 \\
4\end{array}$ & Rejected \\
\hline H4 - "Financial attitude has a significant impact on financial wellness. & \\
\hline FW <--- FA & 0.152 & 0.070 & 4.214 & $* * *$ & Accepted \\
\hline
\end{tabular}

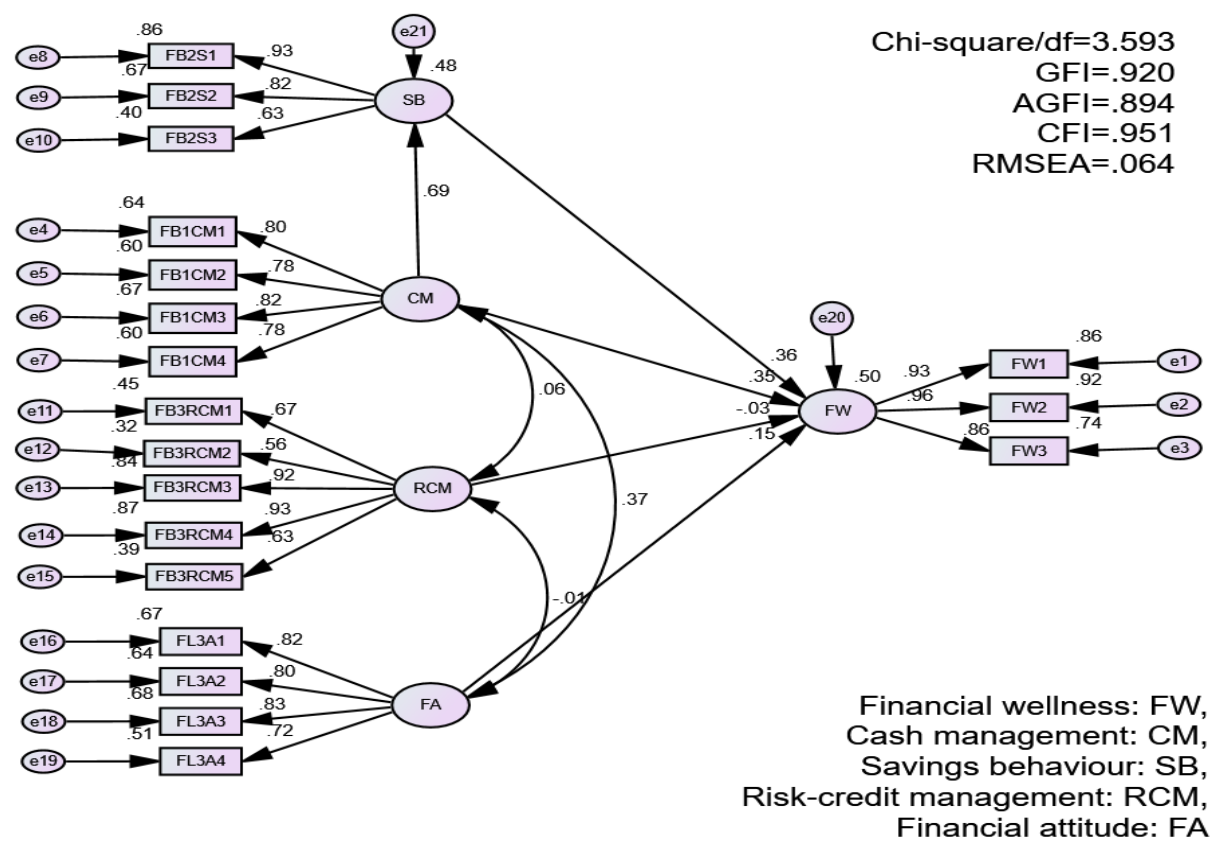

Figure 3. Structure Model 


\section{Mediation Analysis}

The mediating effect of the savings behavior on the financial wellness of rural households has been tested using a bootstrapping method in AMOS (Kline, 2016), (Hopwood, 2007). The results of bootstrapping methods have been shown in Table 10. The total effect of cash management on financial wellness was significant $(\beta=.591, p=0.002)$, such that better cash management led to better financial wellness. The direct effect of cash management on financial wellness was significant $(\beta=.346, p=$ $0.001)$, and the indirect effect of cash management on financial wellness in the presence of savings behavior was also significant $(\beta=.245, \mathrm{p}=0.001)$. The $\mathrm{p}$-value of indirect effect and total effect are > 0 , hence partial mediation exists (Aguinis et al., 2017). The Sobel z-value of $6.4790>2.58$ with p-value of 0.0189 (less than 0.05) indicated that the mediation effect is significant at $95 \%$ confidence interval (Abu-Bader \& Jones, 2021), (Preacher \& Hayes, 2008), (Baron \& Kenny, 1986). The results confirmed that savings behavior significantly mediates the relationship between cash management and financial wellness. Thus, hypothesis H5 is accepted, and we can conclude that savings behavior has a partial mediating effect on the relationship between cash management and financial wellness.

Table 10. Results of bootstrapping for mediation analysis

\begin{tabular}{|l|c|c|l|}
\hline \multicolumn{1}{|c|}{ Type of effect } & Standardized beta & p-value & \multicolumn{1}{c|}{ Remark } \\
\hline Total effect & .591 & .002 & Significant total effect \\
\hline Direct effect & .346 & .001 & Significant indirect effect \\
\hline Indirect effect & .245 & .001 & Significant direct effect \\
\hline
\end{tabular}

\section{DISCUSSION AND CONCLUSION}

The study investigated significant contributors to financial wellness in rural households in the hill districts. These households are members of SHGs and cooperatives, and all are small and marginal farmers. The demographic statistics indicate that most of the members in SHGs and cooperatives are female $(87.4 \%$ ). $76.8 \%$ of members were intermediate and below educated, $70.7 \%$ were between the age group of 30 to 50, average monthly income of $69.1 \%$ members was below INR 9000, and 64.8\% had average monthly savings less than INR 900 per month. Landholding data validate that all are small and marginal farmers. Reliability analysis (Cronbach's alpha $=.820>0.7$ ) of all items confirms the internal consistency of items. Through exploratory factor analysis (EFA) and confirmatory factor analysis (CFA), five constructs such as financial wellness, cash management, savings behavior, riskcredit management, and financial attitude were identified from 19 items. The goodness of fit indices, convergent validity, and discriminant validity support the analysis.

To test the hypothesis, path analysis was conducted. Results revealed that cash management, savings behavior, and financial attitude are significant impacts on financial wellness, which is supported by the hypothesis. The findings are substantiated with the recent literature (CHAVALI et al., 2021), (Gichuhi \& Mwangi, 2021), (Maina et al., 2020). The results indicate that if households have positive attitudes towards financial practices and manage their income effectively with proper and regular savings, their financial wellness will increase. The results also indicate that risk-credit management does not significantly impact financial wellness. However, all items of risk-credit management were loaded significantly in EFA and CFA. It indicates that rural households are aware of insurance and credit schemes, but they do not take full advantage of such schemes. The study inspects the mediating effect and has found that savings behavior has a mediating effect on the relationship of cash management to financial wellness.

According to (Anand et al., 2021), (Word Bank, 2020) financial knowledge contributes to the financial wellness of rural households and makes them more robust for tough times. The study also found that rural households have sound financial knowledge about different financial schemes and welfare programs. The results show that households know the essential difference between financial instruments and are well skilled in day-to-day numerical calculations. The results also found that the financial decision is mainly taken after mutual consent of both husband and wife, demonstrating 
women's empowerment. These results refer that intensive development activities, including financial literacy programs, and the package of financial practices, significantly impact financial wellness. The results show that SHGs and cooperatives play a significant role in implementing financial inclusion programs (Omar \& Inaba, 2020), (Wadhwa, 2020). They not only support income-generating activities but also facilitate knowledge capitalization. Through SHGs, households' savings behavior has increased directly or indirectly, and female participation in financial decision-making has also increased. The study concludes that cash management, savings behavior, financial knowledge, and financial attitude lead to the financial wellness of rural households in hill districts.

\section{PRACTICAL IMPLICATIONS}

The study identified factors of financial wellness through theoretical and empirical analysis. The research findings of the study can be more relevant in the areas of rural development, banking, agriculture, and allied sectors. This study can assist in improving the livelihood programs of rural areas, including financial inclusion, especially those implemented in rural hilly areas. This research finding will also support the policymakers to emphasize more on sustainable livelihood opportunities and customized financial inclusion in the hill districts, which will increase financial knowledge and subsequently improve the financial behavior, and financial attitude. Frequent capacity building, regular information dissemination, and service delivery mechanism can also improve the risk-credit schemes. Overall, an increase in financial knowledge, income, and savings is positively related to economic upliftment and contributes to achieving sustainable development goals.

\section{RESEARCH LIMITATION AND FUTURE RESEARCH DIRECTION}

This research has highlighted that financial wellness is a function of cash management, savings behavior, and financial attitude, where savings behavior mediates the relationship between cash management and financial wellness. This study has some limitations. The research has been conducted on SHGs and Cooperatives members only. Furthermore, the seasonal migration between rural and semi urban areas of rural households in hill districts has not been considered. These two aspects can be considered for future research. Food security and health affect everyone in remotest rural areas and need to be studied.

\section{AUTHOR CONTRIBUTIONS}

Conceptualization: Ajay Purohit, Gaurav Chopra, Parshuram G Dangwal

Data Curation: Ajay Purohit, Gaurav Chopra, Parshuram G Dangwal

Formal Analysis: Ajay Purohit, Gaurav Chopra, Parshuram G Dangwal

Funding Acquisition: Ajay Purohit

Investigation: Ajay Purohit, Gaurav Chopra, Parshuram G Dangwal

Methodology: Ajay Purohit, Gaurav Chopra, Parshuram G Dangwal

Project Administration: Gaurav Chopra, Parshuram G Dangwal

Resources: Ajay Purohit

Software: Ajay Purohit

Supervision: Gaurav Chopra, Parshuram G Dangwal

Validation: Ajay Purohit, Gaurav Chopra, Parshuram G Dangwal

Visualization: Ajay Purohit

Writing - Original Draft: Ajay Purohit

Writing - Review \& Editing: Ajay Purohit, Gaurav Chopra, Parshuram G Dangwal

\section{CONFLICT OF INTEREST STATEMENT}

The authors declare that they have no competing interests.

\section{ACKNOWLEDGEMENT}

All authors contributed equally to the conception and design of the study. 


\section{REFERENCES}

Abdullah, N., Fazli, S. M., \& Arif, A. M. M. (2019). The Relationship between attitude towards money, financial literacy and debt management with young worker's financial well-being. Pertanika Journal of Social Sciences and Humanities, 27(1), 361-387.

Abu-Bader, S., \& Jones, T. V. (2021). Statistical Mediation Analysis Using the Sobel Test and Hayes SPSS Process Macro. International Journal of Quantitative and Qualitative Research Methods, 9(1), 42-61.

Adiputra, I. G. (2021). The Influence of Financial Literacy, Financial Attitude and Locus of Control on Financial Satisfaction: Evidence From the Community in Jakarta. International Conference on Entrepreneurship (ICOEN), 636-654. https://doi.org/10.18502/kss.v5i5.8848

Aguinis, H., Edwards, J. R., \& Bradley, K. J. (2017). Improving Our Understanding of Moderation and Mediation in Strategic Management Research. Organizational Research Methods, 20(4), 665-685. https://doi.org/10.1177/1094428115627498

Ameliawati, M., \& Setiyani, R. (2018). The Influence of Financial Attitude , Financial Socialization , and Financial Experience to Financial Management Behavior with Financial Literacy as the Mediation Variable. International Conference on Economics, Business and Economic Education, 811-832. https://doi.org/10.18502/kss.v3i10.3174

Anand, S., Mishra, K., Verma, V., \& Taruna, T. (2021). Financial literacy as a mediator of personal financial health during COVID-19: A structural equation modelling approach. Emerald Open Research, 2(May), 59. https://doi.org/10.35241/emeraldopenres.13735.2

Aren, S., \& Aydemir, S. D. (2014). A Literature Review on Financial Literacy. Finansal Araştırmalar ve Çalışmalar Dergisi, 6(11), 33-50. https://doi.org/10.14784/jfrs.2014117326

Atmaningrum, S., Kanto, D. S., \& Kisman, Z. (2021). Investment Decisions: The Results of Knowledge, Income, and Self-Control. Journal of Economics and Business, 4(1), 100-112. https://doi.org/10.31014/aior.1992.04.01.324

Baron, R. M., \& Kenny, D. A. (1986). The Moderator-Mediator Variable Distinction in Social Psychological Research. Conceptual, Strategic, and Statistical Considerations. Journal of Personality and Social Psychology, 51(6), 1173-1182. https://doi.org/10.1037/00223514.51.6.1173

Bentler, P. M., \& Bonett, D. G. (1980). Significance tests and goodness of fit in the analysis of covariance structures. Psychological Bulletin, 88(3), 588-606. https://doi.org/10.1037/00332909.88.3.588

Bilal, M., \& Zulfiqar, M. (2016). Financial Wellbeing is the Goal of Financial Literacy. Research Journal of Finance and Accounting, 7(11), 94-103.

Bollen, K. A. (1990). Overall Fit in Covariance Structure Models: Two Types of Sample Size Effects. Psychological Bulletin, 107(2), 256-259. https://doi.org/10.1037/0033-2909.107.2.256

Botha, F., \& New, J. P. de. (2021). Proposal of a short form self-reported financial wellbeing scale for inclusion in the 2026 Census. Australian Population Studies, 5(1), 34-39. https://doi.org/10.37970/aps.v5i1.79

Brüggen, E. C., Hogreve, J., Holmlund, M., Kabadayi, S., \& Löfgren, M. (2017). Financial well-being: A conceptualization and research agenda. Journal of Business Research, 79, 228-237. https://doi.org/10.1016/j.jbusres.2017.03.013

CFPB. (2015). Measuring financial well-being: A guide to using the CFPB Financial Well-Being Scale. In Comsumer Financial Protection Bureau (Issue December). Retrieved from https://www.consumerfinance.gov 


\section{CFPB. (2017). CFPB FINANCIAL WELL-BEING SCALE: SCALE DEVELOPMENT TECHNICAL} REPORT. In Comsumer Financial Protection Bureau. Retrieved from https://www.consumerfinance.gov

CHAVALI, K., RAJ, P. M., \& AHMED, R. (2021). Does Financial Behavior Influence Financial Wellbeing? Journal of Asian Finance, Economics and Business, 8(2), 273-280. https://doi.org/10.13106/jafeb.2021.vol8.no2.0273

Chong, K. F., Sabri, M. F., Magli, A. S., Rahim, H. A. B. D., Mokhtar, N., \& Othman, M. A. (2021). The Effects of Financial Literacy, Self-Efficacy and Self-Coping on Financial Behavior of Emerging Adults. Journal of Asian Finance, Economics and Business, 8(3), 905-915. https://doi.org/10.13106/jafeb.2021.vol8.no3.0905

Chopra, G., \& Madan, P. (2021). Role of 'potential self-efficacy' on e-learning effectiveness : a genderspecific moderated mediation model. Int. J. Learning and Change, 13(2), 190-217.

Chopra, G., Madan, P., Jaisingh, P., \& Bhaskar, P. (2019). Effectiveness of e-learning portal from students' perspective: A structural equation model (SEM) approach. Interactive Technology and Smart Education, 16(2), 94-116. https://doi.org/10.1108/ITSE-05-2018-0027

Choudhary, K., \& Kamboj, S. (2017). A Study of Financial Literacy and Its Determinants: Evidence from India. Asian Journal of Accounting Perspectives, 10(1), 52-72. https://doi.org/10.22452/ajap.vol10no1.4

Coleman, B. E., \& Wynne-williams, J. (2006). Rural Finance in the Lao People's Democratic Republic: Demand, Supply, and Sustainablity. Asian Development Bank. Retrieved from https://www.adb.org/sites/default/files/publication/159368/adbi-rural-finance-lao.pdf

Collins, J. M., \& Urban, C. (2020). Measuring financial well-being over the lifecourse. European Journal of Finance, 26(4-5), 341-359. https://doi.org/10.1080/1351847X.2019.1682631

Coşkuner, S. (2016). Understanding factors affecting financial satisfaction: The influence of financial behavior, financial knowledge and demographics. Imperial Journal of Interdisciplinary Research, 2(5), 377-385.

CPCU. (2020). ILSP: Annual Progress Report - 2019-20. Integrated Livelihood Support Project (ILSP). Retrieved from https://ugvs.org/betaugvs/wp-content/uploads/2020/08/Annual-Report-2019-20ILSP-IFAD.pdf

DAY-NRLM. (2017). A Handbook on SHG - Bank Linkage. Deen Dayal Upadyay Antyodaya Yojana National Rural Livelihoods Mission. Retrieved from https://daynrlmbl.aajeevika.gov.in/Circulars/Handbook on SHG.pdf

DES. (2020). Uttarakhand At A Glance - 2019-20. Directorate of Economics \& Statistics, Department of Planning, Government of Uttarakhand. Retrieved from https://des.uk.gov.in/files/Uttarakhand_at_A_Glance_2019-20.pdf

Despard, M. R., Friedline, T., \& Martin-West, S. (2020). Why Do Households Lack Emergency Savings? The Role of Financial Capability. Journal of Family and Economic Issues, 41(3), 542557. https://doi.org/10.1007/s10834-020-09679-8

Fazli Sabri, M., Reza, T. S., \& Wijekoon, R. (2020). Financial Management, Savings and Investment Behavior and Financial Well-Being of Working Women in the Public Sector. Majalah Ilmiah Bijak, 17(2), 135-153. https://doi.org/10.31334/bijak.v17i2.1008

Field, A. (2018). Discovering Statistics Using IBM SPSS Statistics (5th ed.). SAGE Publications Ltd.

Forouzani, M., \& Mohammadzadeh, L. (2018). Empowerment of the members of rural women's 
cooperatives: The impact of icts in rural districts of Urmia county, Iran. Asian Women, 34(4), 7799. https://doi.org/10.14431/aw.2018.12.34.4.77

Gaisina, S., \& Kaidarova, L. (2017). Financial Literacy of Rural Population as a Determinant of Saving Behavior in Kazakhstan. Rural Sustainability Research, 38(333), 32-42. https://doi.org/10.1515/plua-2017-0010

Garber, G., \& Koyama, S. M. (2017). Policy-effective Financial Knowledge and Attitude Factors in Latin America. In Working Paper Series (Brasília no. 469; Working Paper Series). Retrieved from http://www.bcb.gov.br/pec/wps/ingl/wps469.pdf

Gaskin, J. (2021). CFA: Model Fit Analysis. Retrieved from http://statwiki.gaskination.com/index.php?title=CFA\#Model_Fit

Gautam, Y., \& Andersen, P. (2016). Rural livelihood diversification and household well-being: Insights from Humla, Nepal. Journal of Rural Studies, 44, 239-249. https://doi.org/10.1016/j.jrurstud.2016.02.001

George, D., \& Mallery, P. (2016). IBM SPSS Statistics 23 Step by Step: A Simple Guide and Reference (Fourteenth). Routledge Taylor \& Francis Group.

Gichuhi, A. W., \& Mwangi, L. W. (2021). Financial behaviour and growth of women groups in KenyaA case study of Joyful Women Organisation registered groups in Kajiado county. International Academic Journal of Economics and Finance, 3(6), 317-332.

Gjertson, L. (2016). Emergency Saving and Household Hardship. Journal of Family and Economic Issues, 37(1), 1-17. https://doi.org/10.1007/s10834-014-9434-z

GoUK. (2018). Uttarakhand Vision 2030. Department of Planning, Government of Uttarakhand. Retrieved from http://des.uk.gov.in/files/Uttarakhand_Vision_2030.pdf

Hair, J. F., Hult, G. T. M., Ringle, C. M., \& Sarstedt, M. (2017). A Primer on Partial Least Squares Structural Equation Modeling (PLS-SEM). In Sage (Second). SAGE Publications.

Hair, J. F., Sarstedt, M., Ringle, C. M., \& Gudergan, S. P. (2017). Advanced Issues in Partial Least Squares Structural Equation Modeling. SAGE Publications.

Heath, C. J., Mikuška, J., \& Gillen, M. L. (2018). The Effects of Demographic Characteristics on Financial Well-Being. The Forum for Family and Consumer Issues (FFCI), 22(1). Retrieved from https://www.theforumjournal.org/wp-content/uploads/2019/09/The-Effects-of-DemographicCharacteristics-on-Financial-Well-Being_PDF-FILE-final.pdf

Heo, W., Lee, J. M., \& Park, N. (2020). Financial-related psychological factors affect life satisfaction of farmers. Journal of Rural Studies, 80(August), 185-194. https://doi.org/10.1016/j.jrurstud.2020.08.053

Hooper, D., Coughlan, J., \& Mullen, M. R. (2008). Structural equation modelling: Guidelines for determining model fit. The Electronic Journal of Business Research Methods, 6(1), 53-60. https://doi.org/10.21427/D79B73

Hopwood, C. J. (2007). Moderation and mediation in structural equation modeling: Applications for early intervention research. Journal of Early Intervention, 29(3), 262-272. https://doi.org/10.1177/105381510702900305

Hu, L. T., \& Bentler, P. M. (1999). Cutoff criteria for fit indexes in covariance structure analysis: Conventional criteria versus new alternatives. Structural Equation Modeling, 6(1), 1-55. https://doi.org/10.1080/10705519909540118

IGI-Global. (2021a). What is Financial Attitudes | IGI Global. Retrieved from https://www.igi- 
global.com/dictionary/financial-literacy/58683

IGI-Global. (2021b). What is Financial Behavior | IGI Global. Retrieved from https://www.igiglobal.com/dictionary/financial-education-for-children-and-youth/47372

Iramani, R., \& Lutfi, L. (2021). An integrated model of financial well-being: The role of financial behavior. Accounting, 7(3), 691-700. https://doi.org/10.5267/j.ac.2020.12.007

Ismail, N., \& Zaki, N. D. A. (2019). Does Financial Literacy and Financial Stress Effect the Financial Wellness? International Journal of Modern Trends in Social Sciences, 2(8), 1-11. https://doi.org/10.35631/ijmtss.28001

Ismail, S., Khairuddin, N. S., Alias, N. E., Koe, W. L.-, \& Othman, R. (2018). An Empirical Analysis of Saving Behavior among Malaysian Employees. International Journal of Academic Research in Business and Social Sciences, 8(10), 1070-1080. https://doi.org/10.6007/ijarbss/v8-i10/4822

Jayanthi, M., \& Rau, S. (2017). An Empirical Study on Financial Literacy and Spending Behavior of Rural Household in India. Asian Journal of Management, 8(4), 1115-1119. https://doi.org/10.5958/2321-5763.2017.00170.6

Jin, X., Zhao, Y., Song, W., \& Zhao, T. (2021). Save for Safe: Effect of COVID-19 Pandemic on Consumers' Saving and Spending Behavior in China. Frontiers in Psychology, 12(April), 1-8. https://doi.org/10.3389/fpsyg.2021.636859

Kamakia, M. G., Mwangi, C. I., \& Mwangi, M. (2017). Financial Literacy and Financial Wellbeing of Public Sector Employees: A Critical Literature Review. European Scientific Journal, ESJ, 13(16), 233-249. https://doi.org/10.19044/esj.2017.v13n16p233

Kandpal, D. V., \& Kavidayal, D. P. C. (2020). Financial Inclusion in India Breaking the Myths and Challenges: The Case of Uttarakhand. Test Engineering \& Management, 82(Feb.), 13036-13051. https://doi.org/10.2139/ssrn.3632551

Kesavan, N. (2020). Issues and Challenges in Rural Financial Inclusion - a Review of Issues and Challenges in India. Our Heritage, 68(2), 605-612.

Klapper, L., El-Zoghbi, M., \& Hess, J. (2016). Achieving the sustainable development goals: The role of financial inclusion. Washington, DC: CGAP.

Kline, R. B. (2016). Principles and practices of structural equation modelling. In Methodology in the social sciences (Fourth). The Guilford Press.

Kyriazos, T. A. (2018). Applied Psychometrics: Sample Size and Sample Power Considerations in Factor Analysis (EFA, CFA) and SEM in General. Psychology, 09, 2207-2230. https://doi.org/10.4236/psych.2018.98126

Lee, J. M., \& Hanna, S. D. (2015). Savings goals and saving behavior from a perspective of Maslow's hierarchy of needs. Journal of Financial Counseling and Planning, 26(2), 129-147. https://doi.org/10.1891/1052-3073.26.2.129

Lulaj, E., Dragusha, B., Lulaj, D., Rustaj, V., \& Gashi, A. (2021). Households Savings and Financial Behavior in Relation To the Ability To Handle Financial Emergencies: Case Study of Kosovo. Acta Scientiarum Polonorum. Oeconomia, 20(1), 35-48. https://doi.org/10.22630/aspe.2021.20.1.4

Magendans, J., Gutteling, J. M., \& Zebel, S. (2017). Psychological determinants of financial buffer saving: the influence of financial risk tolerance and regulatory focus. Journal of Risk Research, 20(8), 1076-1093. https://doi.org/10.1080/13669877.2016.1147491

Mahdzan, N. S., Zainudin, R., Abd Sukor, M. E., Zainir, F., \& Wan Ahmad, W. M. (2020). An exploratory study of financial well-being among Malaysian households. Journal of Asian Business 
and Economic Studies, 27(3), 285-302. https://doi.org/10.1108/jabes-12-2019-0120

Maina, J. N., Kiai, R. M., \& Kyalo, T. N. (2020). Cash management practice, SACCO size and Kenya's deposit taking saving and credit co-operatives financial sustainability. Jurnal Perspektif Pembiayaan Dan Pembangunan Daerah, 8(4), 319-330. https://doi.org/10.22437/ppd.v8i4.10161

Mamgain, R. P., \& Reddy, D. N. (2015). Out-Migration From Hill Region of Uttarakhand : Issues and Policy Options. National Institute of Rural Development and Panchayati Raj, Rajendranagar Hyderabad, 1-27.

Martin, K. D., \& Hill, R. P. (2015). Saving and Well-Being at the Base of the Pyramid: Implications for Transformative Financial Services Delivery. Journal of Service Research, 18(3), 405-421. https://doi.org/10.1177/1094670514563496

Masenya, R. W., \& Dickason-Koekemoer, Z. (2020). A conceptual model of the influence of South African investor well-being on risk tolerance. Cogent Economics and Finance, 8(1). https://doi.org/10.1080/23322039.2020.1738809

Michael Collins, J., \& Urban, C. (2020). Measuring financial well-being over the lifecourse. European Journal of Finance, 26(4-5), 341-359. https://doi.org/10.1080/1351847X.2019.1682631

Mulaik, S. A., James, L. R., Alstine, J. Van, Bennett, N., Lind, S., \& Stilwell, C. D. (1989). Evaluation of Goodness-of-Fit Indices for Structural Equation Models. Psychological Bulletin, 105(3), 430445. https://doi.org/10.1037/0033-2909.105.3.430

Muleke, V., \& Muriithi, J. G. (2013). Financial Education on Employees' Financial-Wellbeing in Academia in Tharaka Nithi County in Kenya. European Journal of Business and Management, 5(15), 142-147.

Murari, K. (2019). Managing household finance: An assessment of financial knowledge and behaviour of rural households. Journal of Rural Development, 38(4), 706-733. https://doi.org/10.25175/jrd/2019/v38/i4/150768

Murugesan, R., \& Manohar, V. (2020). Financial Literacy - A Determinant of Investment in Health Insurance. International Journal of Commerce, 8(3), 33-38. https://doi.org/10.34293/commerce.v8i3.2009

Nguyen, T. A. N., Rózsa, Z., Belás, J., \& Belásová, L'. (2017). The effects of perceived and actual financial knowledge on regular personal savings: Case of Vietnam. Journal of International Studies, 10(2), 278-291. https://doi.org/10.14254/2071-8330.2017/10-2/19

OECD/INFE. (2013). Financial Literacy and Inclusion: results of OECD/INPE survey across countries and by gender. Financial Literacy \& Education: Russia Trust Fund, June, 1-175. Retrieved from https://www.oecd.org/daf/fin/financial-

education/TrustFund2013_OECD_INFE_Fin_Lit_and_Incl_SurveyResults_by_Country_and_Ge nder.pdf

OECD. (2013). Output and analysis of subjective well-being measures. In OECD Guidelines on Measuring Subjective Well-being (pp. 179-247). OECD Publishing. https://doi.org/https://doi.org/10.1787/9789264191655-8-en

OECD. (2018). OECD/INFE Toolkit for Measuring Financial Literacy and Financial Inclusion. In OECD (Issue May).

OECD. (2020). OECD/INFE 2020 International Survey of Adult Financial Literacy. Retrieved from www.oecd.org/financial/education/launchoftheoecdinfeglobalfinancialliteracysurveyreport.htm

Omar, M. A., \& Inaba, K. (2020). Does financial inclusion reduce poverty and income inequality in developing countries? A panel data analysis. Journal of Economic Structures, 9(1). 
https://doi.org/10.1186/s40008-020-00214-4

Phani Kumar, T. V. V. (2016). Financial Literacy among Rural Households in Coastal Districts of Andhra Pradesh. International Journal of Engineering and Management Research, 6(4), 209-216. Retrieved from http://hdl.handle.net/10419/183168

PIB. (2019). Categorisation of Farmers. Press Information Bureau, Government of India, Ministry of $\begin{array}{lllll}\text { Agriculture \& } & \text { Farmers } & \text { Welfare. } & \text { Retrieved }\end{array}$ https://pib.gov.in/newsite/PrintRelease.aspx?relid=188051

Podsakoff, P. M., \& Organ, D. W. (1986). Self-Reports in Organizational Research: Problems and Prospects. Journal of Management, 12(4), 531-544. https://doi.org/10.1177/014920638601200408

Potrich, A. C. G., Vieira, K. M., \& Mendes-Da-Silva, W. (2016). Development of a financial literacy model for university students. Management Research Review, 39(3), 356-376. https://doi.org/10.1108/MRR-06-2014-0143

Preacher, K. J., \& Hayes, A. F. (2008). Asymptotic and resampling strategies for assessing and comparing indirect effects in multiple mediator models. Behavior Research Methods, 40(3), 879891. https://doi.org/10.3758/BRM.40.3.879

Predergast, S., Blackmore, D., \& Kempson, E. (2018). FINANCIAL WELLBEING - A SURVEY OF ADULTS IN NEW ZEALAND (Issue April). ANZ Banking Group Limited. https://doi.org/10.13140/RG.2.2.32528.05128

PwC. (2014). Employee Wellness Survey 2014 (Issue April). PricewaterhouseCoopers LLP. Retrieved from https://www.pwc.com/us/en/private-company-services/publications/assets/pwc-employeefinancial-wellness-survey-2014-results.pdf

PwC. (2020). PwC's 9th annual Employee Financial Wellness Survey (Issue May). PricewaterhouseCoopers LLP. Retrieved from https://cygnetinstitute.org/wpcontent/uploads/2021/02/pwc-9th-annual-employee-financial-wellness-survey-2020.pdf

Rampini, A. A., \& Viswanathan, S. (2016). Household Risk Management (NBER Working Paper No. w22293; Issue May, Revised 31 May 2021). Retrieved from https://ssrn.com/abstract=2786471

RBI. (2019). Master Circular - Deendayal Antyodaya Yojana - National Rural Livelihoods Mission (DAY-NRLM). In Reserve Bank of India (RBI/2019-2). Retrieved from https://rbidocs.rbi.org.in/rdocs/notification/PDFs/NT105C9AB07919617490AA6CBC835EE892 36C.PDF

RBI. (2021). National Strategy for Financial Education 2020-2025. Reserve Bank of India. Retrieved from https://m.rbi.org.in/Scripts/PublicationReportDetails.aspx?UrlPage=\&ID=1156

Rickard, K., \& Johnsson, A. (2018). Women's Empowerment and Savings Groups: What Do We Know? 1-20. Retrieved from https://seepnetwork.org/files/galleries/2019-SG-LB-WomensEmpowerment-And-SGs-EN-DIGITAL.pdf

Robb, C. A., \& Woodyard, A. S. (2011). Financial Knowledge and Best Practice Behavior. Journal of Financial Counseling and Planning, 22(1), 60-70.

Shin, S. H., \& Kim, K. T. (2018). Perceived income changes, saving motives, and household savings. Journal of Financial Counseling and Planning, 29(2), 396-409. https://doi.org/10.1891/10523073.29.2.396

Simonova, M. D. (2019). The Economy of Well-Being: Creating Opportunities for People's Well-Being and Economic Growth. In MGIMO Review of International Relations (SDD WORKING PAPER No. 102, 102(5). https://doi.org/10.24833/2071-8160-2020-5-74-375-386 
Skagerlund, K., Lind, T., Strömbäck, C., Tinghög, G., \& Västfjäll, D. (2018). Financial literacy and the role of numeracy-How individuals' attitude and affinity with numbers influence financial literacy. Journal of Behavioral and Experimental Economics, 74(August 2017), 18-25. https://doi.org/10.1016/j.socec.2018.03.004

Stella, G. P., Filotto, U., \& Cervellati, E. M. (2020). A Proposal for a New Financial Literacy Questionnaire. International Journal of Business and Management, 15(2), 34-48. https://doi.org/10.5539/ijbm.v15n2p34

Suryanarayana, M. H., \& Mamgain, R. P. (2017). Estimation of District Level Poverty in Uttarakhand (Issue November). Directorate of Economics and Statistics, Department of Planning, Government of Uttarakhand.

Tanoto, S., \& Evelyn, E. (2019). Financial Knowledge, Financial Wellbeing, and Online Shopping Addiction Among Young Indonesians. Jurnal Manajemen Dan Kewirausahaan, 21(1), 32-40. https://doi.org/10.9744/jmk.21.1.32-40

Topa, G., Zappalà, S., Giorgi, G., \& Europea, U. (2018). Financial Management Behavior Among Young Adults: The Role of Need for Cognitive Closure in a Three-Wave Moderated Mediation Model. Frontiers in Psychology, 9(November), 1-10. https://doi.org/10.3389/fpsyg.2018.02419

Tucker, L. R., \& Lewis, C. (1973). A Reliablity Coefficient for Maximum Likelihood Factor Analysis. Psychometrika, 38(1), 421-422.

UNCTAD. (2015). Access to Financial Services as a Driver for the Post-2015 Development Agenda. UN Policy Brief, $35 . \quad$ Retrieved from http://unctad.org/en/PublicationsLibrary/presspb2015d7_en.pdf

Vieira, K. M., Bressan, A. A., \& Fraga, L. S. (2021). Financial well-being of the beneficiaries of the minha casa minha vida program: Perception and antecedents. Revista de Administracao Mackenzie, 22(2), 1-40. https://doi.org/10.1590/1678-6971/ERAMG210115

Vishwanath, C., Dasgupta, M., \& Sharma, M. (2020). Household Finance in India: Approaches and Challenges (WP-2020-02; Working Paper Series No. WP-2020-02, Issue May).

Vosloo, W., Fouche, J., \& Barnard, J. (2014). The Relationship Between Financial Efficacy, Satisfaction With Remuneration And Personal Financial Well-Being. International Business \& Economics Research Journal (IBER), 13(6), 1455. https://doi.org/10.19030/iber.v13i6.8934

Wadhwa, M. (2020). Accelerating Financial Inclusion in Rural India. Kurukshetra, March, 14-18.

Wahab, N. N., \& Yaacob, Z. (2018). Strategy For Financial Wellbeing Among Public Servants In Malaysia. Journal of Techno Social, 10(2), 50-59. https://doi.org/10.30880/jts.2018.10.02.008

Watkins, M. W. (2018). Exploratory Factor Analysis: A Guide to Best Practice. Journal of Black Psychology, 44(3), 219-246. https://doi.org/10.1177/0095798418771807

Widyastuti, U., Sumiati, A., Herlitah, \& Melati, I. S. (2020). Financial education, financial literacy, and financial Behaviour: What does really matter? Management Science Letters, 10(12), 2715-2720. https://doi.org/10.5267/j.msl.2020.4.039

Wieliczko, B., Kurdyś-Kujawska, A., \& Sompolska-Rzechuła, A. (2020). Savings of small farms: Their magnitude, determinants and role in sustainable development. example of Poland. Agriculture, 10(11), 1-18. https://doi.org/10.3390/agriculture10110525

Woodyard, A. (2013). Measuring Financial Wellness. Consumer Interests Annual, Volume 59, 6.

Woodyard, A., \& Robb, C. (2012). Financial Knowledge and the Gender Gap. Journal of Financial Therapy, Volume 3(Issue 1). https://doi.org/10.4148/jft.v3i1.1453 
Word Bank. (2020). In India, women's self-help groups combat the COVID-19(Coronavirus) pandemic. The World Bank. Retrieved from https://www.worldbank.org/en/news/feature/2020/04/11/women-self-help-groups-combatcovid19-coronavirus-pandemic-india

Xia, Y., \& Yang, Y. (2019). RMSEA, CFI, and TLI in structural equation modeling with ordered categorical data: The story they tell depends on the estimation methods. Behavior Research Methods, 51(1), 409-428. https://doi.org/10.3758/s13428-018-1055-2

Zhan, M., Anderson, S. G., \& Scott, J. (2006). Financial knowledge of the low-income population: Effects of a financial education program. Journal of Sociology and Social Welfare, 33(1), 53-74. Retrieved from https://scholarworks.wmich.edu/jssw/vol33/iss1/4

Zulaihati, S., \& Widyastuti, U. (2020). Determinants of consumer financial behavior: Evidence from households in Indonesia. Accounting, 6(7), 1193-1198. https://doi.org/10.5267/j.ac.2020.9.008

\section{NOTES}

Note 1. Small and Marginal farmers who have less than 2-hectare operational agriculture landholdings. The average landholding in Uttarakhand is 0.85 hectares (PIB, 2019).

Note 2. Panchasutras - Regular meetings; Regular savings; Regular inter-loaning; Timely repayment; and Up-to-date books of accounts (RBI, 2019).

\section{Copyrights}

Copyright for this article is retained by the author(s), with first publication rights granted to the journal. This is an open-access article distributed under the terms and conditions of the Creative Commons Attribution license (https://creativecommons.org/licenses/by/4.0). 